\title{
MANAGEMENT OF SMALL CENTRAL PERFORATION BY TISSUE MYRINGOPLASTY AND CONVENTIONAL MYRINGOPLASTY- A COMPARATIVE STUDY
}

\author{
Monica Karam¹, Yumnam Tomba Singh2, Mayengbam Madhumangal Singh ${ }^{3}$
}

${ }_{1}^{1}$ Senior Resident, Department of ENT, Jawaharlal Nehru Institute of Medical Sciences, Porompat, Imphal East, Manipur. ${ }^{2}$ Assistant Professor, Department of ENT, Jawaharlal Nehru Institute of Medical Sciences, Porompat, Imphal East, Manipur. 3 Professor and HOD, Department of ENT, Jawaharlal Nehru Institute of Medical Sciences, Porompat, Imphal East, Manipur.

\section{ABSTRACT}

\section{BACKGROUND}

Adipose tissue myringoplasty is a technique for closing small perforation in the tympanic membrane. It is a safe and cost-effective technique and can be performed in day-care settings.

Objective- To determine the effectiveness of tisssue myringoplasty in comparison to that of the conventional myringoplasty.

\section{MATERIALS \& METHODS}

A non-randomized controlled trial was taken up in the Department of Otorhinolaryngology, JNIMS during the period Aug 2015-July 2017. Uncomplicated patients having small perforations attending the department were the study subjects. Tissue myringoplasty and the conventional myringoplasty were performed to equal number of eligible patients on alternate case basis. The studysubjects were then followed up for a minimum period of three months to assess the outcome.

\section{RESULTS}

Success rate by conventional myringoplasty was found to be $93.33 \%$ whereas for tissue myringoplasty it was $84.44 \%$.

\section{CONCLUSION}

Although the effectiveness of tissue myringoplasty was slightly lower than that of the conventional technique, taking into consideration the simplicity, safety and cost-effectiveness associated with it, tissue myringoplasty can be considered the procedure of choice in patients with suitable tympanic membrane perforation.

\section{KEYWORDS}

Adipose Tissue Myringoplasty, CSOM, Small Perforation, Temporalis Fascia.

HOW TO CITE THIS ARTICLE: Karam M, Singh YT, Singh MM. Management of small central perforation by tissue myringoplasty and conventional myringoplasty- a comparative study. J. Evolution Med. Dent. Sci. 2018;7(08):975-977, DOI: $10.14260 /$ jemds/2018/223

\section{BACKGROUND}

Myringoplasty is described as plastic repair of a defect in tympanic membrane. The trend to close tympanic membrane perforation was started as early as 1640 when Marcus Benzer (1640) tried to repair tympanic membrane perforation using pig's bladder at the end of an ivory tube and placing it against tympanic membrane. ${ }^{1}$

The surgical repair of tympanic membrane perforation was described as myringoplasty by Berthold in 1878.2 Subsequently came to history Pollack in 1882 with elastic collodion membrane, Tangemam in 1882 with skin graft, Blake in 1887 with cigarette paper patch, Okuneff in 1895 with trichloroacetic acid, Stenson in 1936 with Cargill's membrane (sheep's mesentery), Unger in 1947 with gold foil patches covered with scarlet red ointment, Fritz Zollner in 1956 with fascia lata and Schaffer using acrylic seal in 1956. Heerman in 1958 started using temporalis fascia to repair tympanic membrane perforation. ${ }^{3}$

'Financial or Other Competing Interest': None.

Submission 26-01-2018, Peer Review 08-02-2018,

Acceptance 10-02-2018, Published 19-02-2018.

Corresponding Author:

Dr. Monica Karam,

Department of ENT,

Jawaharlal Nehru Institute of Medical Sciences,

Porompat, Imphal East-795005,

Manipur.

E-mail: monicakaram76@gmail.com

DOI: $10.14260 /$ jemds $/ 2018 / 223$

\section{(c) $(1)(5)$}

Amongst all these materials, temporalis fascia has emerged as the most generally favoured material. Ringerberg JC (1962) started using fat from ear lobule which he claimed to be readily procured and easier to handle 4 .

The aim of this study was to determine the effectiveness of adipose tissue myringoplasty in comparison to the conventional myringoplasty (using temporalis fascia).

\section{MATERIALS AND METHODS}

A non-randomized controlled trial was conducted at JNIMS in the department of Otorhinolaryngology in which all patients aged 21 years or older attending the Otorhinolaryngology OPD during the two years' period from August 2015 to July 2017 were included as the study subjects. Only the patients having normal routine investigation results and having dry small central perforation for at least six weeks prior to the study period and which showed no evidence of acute infection were selected. Patients with tympanosclerosis, head injury or having associated otitis externa were excluded from the study as these conditions could confound the study outcome. All the eligible subjects were coded consecutively, and all the odd-coded patients were treated with tissue myringoplasty whereas the entire even-coded patients underwent the conventional myringoplasty.

An informed written consent was obtained from each of the eligible study subjects before the intervention was given. All the patients were followed up for a minimum period of three months and the success rate in terms of closure of 
perforation, mean audiometric improvement and gain in hearing capacity were measured.

Data analysis was done by using both descriptive (mean, proportion, \%) as well as analytical (chi-square and its modifications) statistical tests. SPSS v21.0 was used for the purpose. A p value of less than 0.05 was considered as statistically significant.

\section{Surgery Procedure}

In tissue myringoplasty group, a large piece of fat was harvested from ear lobule under local anaesthesia following pre-medication. The size of the fat graft was made at least double the size of perforation.

The margin of perforation was de-epithelised circumferentially. Gelfoam in small pieces was introduced into the middle ear cavity to prevent adhesion between graft and promontory. Next, fat was wedged into the perforation in a dumb-bell shape avoiding injury to middle ear mucosa. Graft supported by Gelfoam and a small aural pack impregnated with antibiotic ointment was put in external auditory canal and dressing was applied. Post operatively, patients were put on oral antibiotics, anti-histaminics and decongestants and nasal drops for seven days. They were advised to avoid blowing of nose, straining, lifting heavy objects. Patients were evaluated at 7 days, 1 month and 3 months.

In the conventional myringoplasty group, the tympanic membrane was repaired by conventional method (underlay technique) using temporalis fascia via endo-aural approach. The margin of perforation was made raw for about $2 \mathrm{~mm}$ all around. A curvilinear incision was made over the posterior canal wall $8 \mathrm{~mm}$ away from the tympanic annulus. At 6 O'clock and 12 O'clock position, this incision was extended medially $1 \mathrm{~mm}$ sort of tympanic annulus. A tympanomeatal flap was elevated. The condition of middle ear and ossicles was checked. The middle ear was packed with Gelfoam. Graft was placed medial to annulus and edges of graft were tucked under the drum remnant. The tympanomeatal flap was repositioned and supported by Gelfoam. An Antibiotic-soaked ribbon gauge was given. The same post-operative direction as in Tissue Myringoplasty Group was given. The patients were hospitalised for few days (2-3 days) to ensure adequate care. Discharge was done with proper advice. Patients were followed up at 7 days, 1 month and 3 months Use of antihistaminics was continued for a minimum period of one month.

\section{RESULTS}

Altogether 90 study subjects participated in the study (45 each in tissue myringoplasty group and conventional myringoplasty group). All of them could be followed up for the desired three months post-operatively. Almost two-thirds of the patients in both the groups were aged between 21-30 years. The difference in age in the two groups was comparable. Males significantly outnumbered females. And Chronic Suppurative Otitis Media (CSOM) was the main symptomatology when the patients reported in the OPD. (Table 1 and 2) But, the difference in proportion among the two groups was not statistically significant.

\begin{tabular}{|c|c|c|c|}
\hline & $\begin{array}{c}\text { Tissue } \\
\text { Myringoplasty } \\
\text { Group (\%) }\end{array}$ & $\begin{array}{c}\text { Coventional } \\
\text { Myringoplasty } \\
\text { Group (\%) }\end{array}$ & $\begin{array}{l}X^{2} \text { value } \\
\text { (P value) }\end{array}$ \\
\hline \multicolumn{4}{|l|}{$\begin{array}{l}\text { Age (in } \\
\text { Years) }\end{array}$} \\
\hline $21-25$ & $19(42.2)$ & $16(35.6)$ & \multirow{5}{*}{$\begin{array}{c}8.528 \mathrm{df}=4 \\
(>0.05)\end{array}$} \\
\hline $26-30$ & $11(24.4)$ & 13 (28.9) & \\
\hline 31-35 & $8(17.9)$ & $3(6.7)$ & \\
\hline $36-40$ & 5 (11.1) & $3(6.7)$ & \\
\hline$\geq 41$ & $2(4.4)$ & $10(22.2)$ & \\
\hline $\begin{array}{c}\text { Sex } \\
\text { Male } \\
\text { Female }\end{array}$ & $\begin{array}{l}26(57.8) \\
19(42.2)\end{array}$ & $\begin{array}{l}35(77.8) \\
10(22.2)\end{array}$ & \multirow[t]{2}{*}{$\begin{array}{l}4.1 \mathrm{df}=1 \\
(<0.05)\end{array}$} \\
\hline & & tion & \\
\hline
\end{tabular}

\begin{tabular}{|c|c|c|c|}
\hline $\begin{array}{c}\text { Sympto } \\
\text { matology }\end{array}$ & $\begin{array}{c}\text { Tissue } \\
\text { Myringoplasty } \\
\text { Group (\%) }\end{array}$ & $\begin{array}{c}\text { Conventional } \\
\text { Myringoplasty } \\
\text { Group (\%) }\end{array}$ & P value \\
\hline CSOM & $36(80.0)$ & $30(66.7)$ & $\begin{array}{c}2.197 \\
\mathrm{df}=1 \\
(>0.05)\end{array}$ \\
\hline Traumatic & $5(11.1)$ & $10(22.2)$ & \\
\hline $\begin{array}{c}\text { Failed } \\
\text { conventional } \\
\text { myringoplasty }\end{array}$ & $4(8.9)$ & - & - \\
\hline $\begin{array}{c}\text { Failed tissue } \\
\text { myringoplasty }\end{array}$ & - & $5(11.1)$ & - \\
\hline
\end{tabular}

Table 2. Distribution of study subjects by symptomatology

Table 3 shows the success rate in terms of perforationclosure, audiometric improvement and post-operative hearing gain in both the groups. Perforation-closure was found in $84 \%$ in the tissue myringoplasty group which was slightly lower than the figure of $93 \%$ in the conventional myringoplasty group. The mean audiometric improvement (in $\mathrm{dB}$ ) in the former group was also found to be slightly less than the latter group (10 Vs 15). Also, the post-operative hearing gain was a little lower in the former group (92\% Vs 95\%).

\begin{tabular}{|c|c|c|}
\hline Success Rate & \begin{tabular}{|c|} 
Tissue \\
Myringoplasty \\
(n=45) (\%)
\end{tabular} & $\begin{array}{c}\text { Conventional } \\
\text { Myringoplasty } \\
(n=45)(\%)\end{array}$ \\
\hline Perforation-closure & $38(84.4)$ & $42(93.3)$ \\
\hline $\begin{array}{l}\text { Mean Audiometric } \\
\text { Improvement }\end{array}$ & & \\
\hline $\begin{array}{c}\text { Conductive hearing loss pre- } \\
\text { operatively (in dB) }\end{array}$ & 29.04 & 30 \\
\hline $\begin{array}{c}\text { Conductive hearing loss post- } \\
\text { operatively (in } \mathrm{dB} \text { ) }\end{array}$ & 19 & 15 \\
\hline Audiometric improvement & 10.04 & 15 \\
\hline Post-operative hearing gain & $35(92.1)$ & 40 (95.2) \\
\hline
\end{tabular}

\section{DISCUSSION}

Ringenberg first described tissue myringoplasty with a success rate of $87 \%$ for small perforation. ${ }^{4}$ The success rates of tissue myringoplasty as reported by various researchers, till then, are $82.4 \%, 90 \%, 81.6 \%, 87 \%$ and $88.2 \% 5,6-9$ The present study finding of $84.4 \%$ is more or less comparable with the earlier study findings.

The present study had a limitation in that the studysubjects in the two arms of intervention could not be matched for age and sex. This might have confounded the study finding. Another limitation was the small sample size 
itself resulting to very small figures inside cells while trying to apply robust statistical tests for comparison.

In spite of these limitations, the current study found out that effectiveness of tissue myringoplasty is not that bad compared to the conventional myringoplasty.

Although the effectiveness is slightly on the lower side compared to the conventional technique, taking into consideration the simplicity, safety and cost-effectiveness associated with tissue myringoplasty, the procedure is a useful technique giving lesser burden to the patients. It may be noted that, tissue myringoplasty can be done on day-care basis and does not warrant hospitalization. Earlier researchers also pointed out the same advantages for small perforations in the tympanic membrane. ${ }^{4-10}$ Another added advantage is that, this technique can be used when the conventional method fails (as found out from the current study).Florino $F$ et al also had similar finding from their study. ${ }^{11}$

\section{CONCLUSION}

Tissue myringoplasty is almost as effective as the conventional myringoplasty. As the technique is relatively safer than the conventional one with the simplicity of technique and is of short duration, it can be considered the procedure of choice in patients with suitable tympanic membrane perforation.

Bigger studies with more stringent experimental designs are recommended to determine the true effectiveness of this method.

\section{REFERENCES}

[1] Benzer M. Disputatio de auditione lease. Trans Am Acad Ophthalmol Otolaryngol 1963;67:233-9.

[2] Berthold E. Uber myringoplastic. Med-chircentralb 1879;14:195-207.

[3] Heerman H. Tympanic membrane plastic with temporal fascia. Hals-Nasen-Ohrenh 1960;9:136.

[4] Ringeberg JC. Fat graft tympanoplasty. Laryngoscope 1962;72(2):188-92.

[5] Chalishazar U. Fat plug myringoplasty. Indian J Otolaryngol Head Neck Surg 2005;57(1):43-4.

[6] Ozgursoy OB, Yorulmaz I. Fat graft myringoplasty: a cost-effective but underused procedure. J Laryngol Otol 2005;119(4):277-9.

[7] Landsberg R, Fishman G, DeRowe A, et al. Fat graft myringoplasty: results of a long term follow up. J Otolaryngol 2006;35(1):44-7.

[8] Kim DK, Park SN, Yeo SW, et al. Clinical efficacy of fatgraft myringoplasty for perforation of different sizes and locations. Acta Otolaryngol 2011;131(1):22-6.

[9] Hegazy HM. Fat graft myringoplasty-a prospective clinical study. Egypt J Ear Nose Throat Allied Sec 2013;14(2):91-5.

[10] Gold SR, Chaffoo RA. Fat myringoplasty in the Guineapig. Laryngoscope 1991;101(1 Pt 1):1-5.

[11] Florino F, Barbieri F. Fat graft myringoplasty after unsuccessful tympanic membrane repair. Eur Arch Otorhinolaryngol 2007;264(10):1125-8. 